de trefpunten van de handel. Wat betreft de toename van de vraag geeft Jahnke aan dat de lange perioden van vasten en onthouding in het christelijke geloof hebben bijgedragen tot een hogere visconsumptie en dat de bevolking in tijden van vleesschaarste in vis, als bron van eiwitten, een goed substituut zag. Ten slotte gaat Jahnke nog in op de vraag wat deze veranderingen voor de inheemse visserij betekenden. We zien dat de visserij in de westelijke Oostzee net als op de kusten van IJsland beoefend werd vanuit tijdelijke nederzettingen. In de gebieden die Jahnke bespreekt vonden boeren en andere bevolkingsgroepen met een laag inkomen in tijdelijke hutjes hun onderkomen. Zij vormden ad hoc vissersgroepen van vijf tot acht man en gingen met open schuiten uit vissen. De vis kon pas opgekocht worden als deze op het strand was gebracht. In de twaalfde en dertiende eeuw konden kooplieden uit Bardowick en Lübeck vanwege hun belangen in zout uit de zoutpannen van Luneburg de handel in haring monopoliseren. Dit had tot gevolg dat onder andere de vissers uit de Nederlanden naar nieuwe vangstgebieden uit gingen zien. Uiteindelijk had de monopoliepositie van de Lübeckers daardoor nadelige gevolgen voor de haringvisserij in de westelijke Oostzee.

Uiteindelijk schuilt het belang van het boek vooral in het feit dat door alle auteurs een koppeling is gemaakt van veranderingen in de visserij, vishandel en visconsumptie met lange termijn ontwikkelingen. Enkele van deze ontwikkelingen zijn, de christianisering van Europa, waardoor het eten van vis op vastendagen gebruikelijk werd en de toename van de bevolking omstreeks I300, die zodanig was dat de graanproductie opgevoerd moest worden. Dit laatste had tot gevolg dat het verbouwen van graan de veeteelt ging verdringen, waardoor vleestekorten ontstonden. Een omvangrijkere bevolking en vleestekorten leidden op hun beurt tot een hogere visconsumptie. Ontwikkelingen in de visserij en de vishandel worden eveneens in verband gebracht met de ontwikkeling van een markt gebaseerd op een geldeconomie. In de zeventiende eeuw werd het werk van vissersvrouwen uiteindelijk ook steeds meer gekoppeld aan de geldeconomie, zoals blijkt uit het essay van Annette de Wit, die eerder over dit onderwerp in TSEG publiceerde.

\title{
Herman Ketting
}

Kees Camfferman en Bob R.C.J. van den Brand, Broncommentaren, deel 8, Jaarverslagen van Nederlandse ondernemingen vanaf 1811 tot 2005, onder eindredactie van G.A.M. Van Synghel (Den Haag: Instituut voor Nederlandse Geschiedenis, 20IO), I42 p. ISBN 978905216 I73 O.

Op vrijdag 28 oktober 20 Io vond bij het ING in Den Haag de feestelijke presentatie plaats van deel 8 van de serie Bronnencommentaren, gewijd aan jaarverslagen van Nederlandse ondernemingen. De feestelijke presentatie was tegelijkertijd een beetje weemoedig. Het achtste deel is namelijk tevens ook het laatste deel in de reeks gedrukte Bronnencommentaren. De reeks, gestart in 1982 , had ten doel mogelijke koudwatervrees bij onderzoekers, archivarissen, genealogen en andere historisch belangstellenden bij het gebruik van bronnen weg te nemen. Ze werden op weg geholpen met een analyse van de administratieve context en van de informatie- en de gebruikswaarde van de behandelde bronnen. Tegelijkertijd waren de bronnencommentaren bedoeld als stimulans voor bronnenkritische bespiegelingen. 
Hoewel de initiatiefnemers zich ongetwijfeld tot een zo breed mogelijk onderzoekerspubliek wilden wenden, lijken de Bronnencommentaren vooral bedoeld voor de doelgroep van het TSEG. Het zijn namelijk vooral economisch- en sociaal-historici geweest die met hun kennis en ervaringen een meer dan evenredige bijdrage hebben geleverd aan de reeks. Als resultaat hiervan zijn vooral voor economisch- en sociaal-historici relevante bronnen onder de loep genomen. Zwaartepunten in de geanalyseerde bronnen zijn bronnen met betrekking tot de armenzorg en sociale zekerheid, de registratie van vreemdelingen, de registratie van onroerend goed en boedelinventarissen. Een ander opvallend cluster vormen bronnen die betrekking hebben op de nijverheid zoals de Staat van Fabrieken en Werkwinkels, de registers van de Dienst van het Stoomwezen en de Hinderwetbescheiden. Daarbij ligt qua periode de nadruk sterk op de negentiende eeuw. Maar ook bronnen uit de middeleeuwen en het ancien regime (zoals bronnen betreffende de registratie van onroerend goed) en de twintigste eeuw (zoals bronnen voor de criminaliteit en de strafrechtspleging) blijven niet onbesproken.

Deel 8 is vooral bedoeld als een handleiding balanslezen in historisch perspectief. Het gaat daarbij om de financiële kern van het jaarverslag, de jaarrekening, van Nederlandse particuliere ondernemingen met de juridische vorm van een kapitaalvennootschap. Beginpunt van de behandelde periode is I8II, het jaar waarin in de Code de Commerce, de invoering van de aandelenvennootschap met beperkte aansprakelijkheid als gestandaardiseerde privaatrechtelijke organisatievorm is vastgelegd. Het eindpunt is 2005 , het jaar waarin de International Financial Reporting Standards (IFRS) is ingevoerd voor beursgenoteerde ondernemingen.

Camfferman en Van den Brand geven een beknopt historisch overzicht van de jaarverslaggeving met aandacht voor onder meer de veranderende functies, het ontstaan van conventionele normen, de invloed van veranderende bedrijfseconomische opvattingen, Amerikaanse invloeden, de vermaatschappelijking van de onderneming en de internationale harmonisatie. Ook vatten zij de administratieve ontstaansgeschiedenis en de historische ontwikkeling van de regelgeving rondom de jaarverslaggeving bondig samen.

In het bronnencommentaar is de focus vooral gericht op beursgenoteerde ondernemingen en op industriële ondernemingen. Zo blijven de jaarrekeningen van banken, verzekeringsinstellingen en andere dienstverlenende ondernemingen bij de visuele kennismaking en analyse buiten beschouwing. Karakteristieke ontwikkelingen in de jaarrekeningen van Nederlandse ondernemingen tussen het midden van de negentiende en het midden van de twintigste eeuw worden behandeld aan de hand van grote industriële ondernemingen (Biliton, de Nederlandsch-Indische Gas Maatschappij, Lever's Zeep Maatschappij, Van Berkel's Patent, Philips en De 'Koninklijke, De Nederlandse houdstermaatschappij van de Koninklijke/Shell groep) en een spoorwegonderneming, de Hollandsche IJzeren Spoorweg-Maatschappij. Bij het bronnenkritisch commentaar komen relevante zaken aan de orde zoals de betrouwbaarheid van de gegevens in de jaarrekening en de interpretatie daarvan. De conclusie van de auteurs is tegelijkertijd een grote waarschuwing aan de onderzoekers: de rijkdom aan en de informatie van de cijfers in de jaarverslagen dienen altijd getoetst te worden aan de specifieke omstandigheden. Ook al zijn cijfers soms (grotendeels) onbruikbaar zoals in het geval van een onderneming die tot ver na de Tweede Wereldoorlog de techniek van de stille reserve in extreme mate doorvoerde door vrijwel alle vaste activa tegen een gulden te waarderen, dan nog behoudt het jaarverslag zijn waarde als historische bron. 
Bronnencommentaar 8 - met als bijlagen een verklarende woordenlijst, overzichten van vindplaatsen en van gedrukte en digitale bronnen en een beknopt literatuuroverzicht - is een uiterst praktisch hulpmiddel voor onderzoekers die gebruik maken van jaarverslagen, zowel voor beginners als voor gevorderden. Hierbij wil ik niet onvermeld laten dat de Economisch-Historische Bibliotheek van het Nederlandsch Economisch Historisch Archief (NEHA) de beheerder is van de omvangrijkste collectie historische jaarverslagen in Nederland. Deze collectie omvat jaarverslagen van ruim 9.000 Nederlandse ondernemingen.

Voor belangstellenden die nog niet vertrouwd zijn met de Broncommentaren is er het prettige bericht dat de delen een tot en met zeven in de reeks digitaal toegankelijk zijn via de website van het ING: www.inghist.nl. Over de (digitale) toekomst van de Bronnencommentaren wordt verder nagedacht.

Jacques van Gerwen

Internationaal Instituut voor Sociale Geschiedenis/NEHA

Josef Ehmer en Catharina Lis (eds.), The idea of work in Europe from antiquity to modern times (Farnham: Ashgate, 2009) 368 p. IsB 978 o 7546 64IO 9.

De kennis van arbeiders en arbeidsomstandigheden in het verleden is dankzij de inspanning van tal van sociale historici in de afgelopen decennia geweldig toegenomen, en de stroom studies hierover is nog lang niet opgedroogd. Begrijpelijkerwijs en terecht ligt bij deze studies de nadruk op archiefonderzoek naar de daadwerkelijke omstandigheden van de werkende klassen: hoe werkenden - zowel werknemers als hun werkgevers - dachten over hun beroepsmatige bezigheden is echter vaak veel moeilijker te achterhalen. Als men al voldoende geletterd was om de schrijfkunst machtig te zijn, schreven werkenden zelden over hun werk, of werk in het algemeen. Gedachten met betrekking tot werk zijn dan ook meestal alleen bewaard gebleven vanuit het oogpunt van degenen die niet van 's ochtends vroeg tot 's avonds laat hoefden te sloven om in het levensonderhoud te voorzien: geestelijken, intellectuelen, en zonder meer degenen die het zich konden financieel veroorloven om tijd te besteden aan intellectuele bezigheden.

De intellectuele geschiedenis van werk is wellicht mede daardoor een verhoudingsgewijs onontgonnen gebied: sociale historici hebben over het algemeen andere onderzoeksprioriteiten, terwijl ook de beoefenaren van de intellectuele geschiedschrijving meestal andere prioriteiten hebben - in het bijzonder de ontwikkelingen in het denken over godsdienst en staatsinrichting. De studies waarin de intellectuele geschiedenis van het concept 'werk' centraal staat zijn dan ook - zelfs met het hier te recenseren boek - op de vingers van één hand te tellen. Ze worden allemaal genoemd in The idea of work in Europe from antiquity to modern times, een bundeling van bijdragen van verschillende Europese historici over het denken over werk in Europa, voortgekomen uit een in 2003 gehouden conferentie over de beeldvorming van werk en werkenden. De titel, hoewel strikt genomen niet onjuist, is enigszins misleidend: het bevat één artikel over het beeld van werk in de oudheid, middeleeuwse beeldvorming komt alleen zijdelings ter sprake, en de negentiende en twintigste eeuw komen in het geheel niet aan bod. Het zwaartepunt ligt op de vroegmoderne tijd, waarbij 